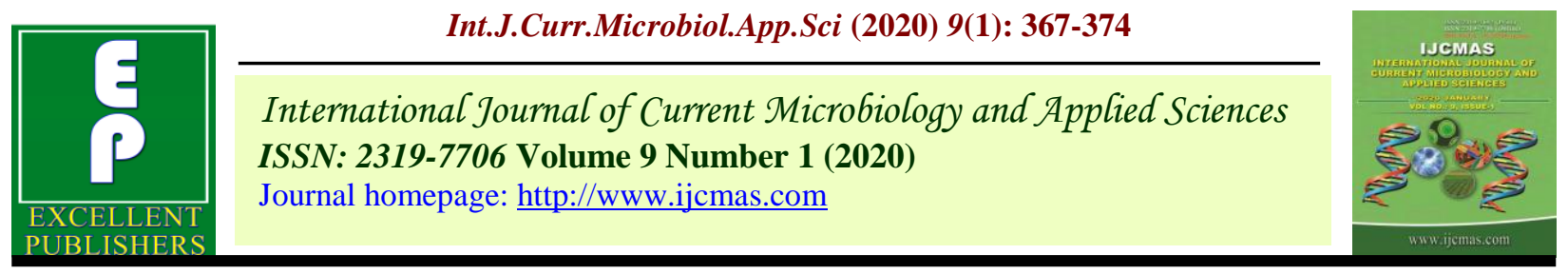

Original Research Article

https://doi.org/10.20546/ijcmas.2020.901.041

\title{
Studies on the Effect of Nitrogen Levels on Growth, Yield Components and Quality of Red Cabbage (Brassica oleracea var. capitata f. rubra)
}

\author{
Abhilash Kavalgi*, R. Rajyalakshmi, K. Uma Jyothi and K. Uma Krishna \\ Dr. YSR Horticultural University, Venkataramannagudem, Tadepalligudem - 534 101, \\ Andhra Pradesh, India
}

Keywords

Red cabbage,

Nitrogen levels,

Growth, Yield

components and

Quality

Article Info

Accepted:

15 December 2019

Available Online:

20 January 2020

\section{A B S T R A C T}

The investigation entitled Studies on the effect of nitrogen levels on growth, yield and quality of red cabbage (Brassica oleracea var. capitata f. rubra) was carried out in Rabi season 2018-2019 at Mango Research Station, Nuzvid, Krishna Dist. (A.P.). Study included four levels of nitrogen (80, 120, 160 and $200 \mathrm{Kg}$ Nitrogen per hector) each replicated thrice in FRBD. Nitrogen levels significantly influenced the growth, yield and quality parameters at all the growth stages. Among all the treatments, significantly highest plant height $(34.93 \mathrm{~cm})$, plant spread $(53.81 \mathrm{~cm})$, number of heading leaves per plant $(23.18)$ and number of loose leaves per plant (13.87) recorded at final harvest. Among yield and yield attributing characters maximum head circumference $(47.12 \mathrm{~cm})$, head length $(16.77 \mathrm{~cm})$, head volume $(950.55 \mathrm{cc})$, head compactness $(1.60)$, head weight $(616$ $\mathrm{g}$ ), head yield per plot $(49.26 \mathrm{~kg})$, Estimated head yield $\left(382.15 \mathrm{q} \mathrm{ha} \mathrm{h}^{-1}\right)$ and dry matter production (11.67\%) with minimum days to head initiation (46.77days) and head harvest (85.03days) were recorded by $200 \mathrm{~kg}$ nitrogen per hector and the same was also maintained best quality with respect to anthocyanin content (117 $\mathrm{mg} / 100 \mathrm{~g})$, ascorbic acid content $(38.32 \mathrm{mg} / 100 \mathrm{~g})$ and $\operatorname{TSS}\left(8.34^{\circ}\right.$ Brix $)$.

\section{Introduction}

Red cabbage (Brassica oleracea var. capitata f. rubra) is also known as purple cabbage or red kraut. It is an important fancy and highly nutritive exotic vegetable. It belongs to the family brassicaceae and comes under the subgroup rubra of cabbage (Brassica oleracea var. capitata L.). It is having chromosome number $2 \mathrm{n}=2 \mathrm{X}=18$. Red cabbage is a native crop in the Mediterranean region of Europe and now grows all over the world as a fresh market vegetable. Red cabbage synthesized and accumulated anthocyanin at all the developmental stages of vegetative growth (Yuan, 2009).It is a cool season crop and widely grown in temperate and subtropical region of India. The transition from vegetative to reproductive growth is triggered by temperature. The optimum temperature for 
growth is $15-18^{\circ} \mathrm{C}$. It can tolerate freezing temperatures but is less tolerant to high temperatures (More, 2006).It is a rich source of anthocyanin, proteins, fats and minerals like calcium, phosphorus, potassium, sulphur etc. and vitamins viz. $A, B_{1}, B_{2}$ and $C$. Red cabbage distinguished by the presence of exceptional health enhancing properties like anticancer properties due to the presence of Indole-3-Carbinol and many beneficial sensory traits, which has become more and more important in recent years (Wojciechowska et al., 2007).In India, cabbage including red cabbage is cultivated in an area of 4.03 lakh hectares producing 91.92 lakh metric tonnes (NHB, 2019).

Red cabbage is a heavy feeder of mineral elements and it removes large amount of macronutrients from the soil. Thus, a major constraint in increasing crop yields is the supply of nutrients (Arakari et al., 1956). Among the nutrients, nitrogen plays the most important role to promote vigorous vegetative growth, attractive colour, higher yield and good quality heads. It is usually the most abundant element in plants. It has essential role as a constituent of protein, nucleic acids, chlorophyll and growth hormones (Hossain et al., 2011).Very few studies on the growth, yield and quality of red cabbage have been carried out in our country. Therefore, the study of cultivation practices with respect to suitable fertilizer levels is a pre-requisite for any new crop assessment to achieve more returns per unit area. Since, red cabbage crop has been introduced recently in our country there is a need to standardize the fertilizer to suit the local conditions.

\section{Materials and Methods}

An investigation entitled Studies on the effect of nitrogen levels on growth, yield and quality of red cabbage (Brassica oleracea var. capitata f. rubra) was carried out during rabi season, 2018-2019 at MRS, Nuzvid, Krishna district (A.P.). The location falls under Agroclimatic zone-10, east coastal plain and hills (Krishna-Godavari zone) with an average rainfall of $900 \mathrm{~mm}$, located at an altitude of 34 $\mathrm{m}$ (112 feet) above mean sea level. The location is geographically situated at $16^{\circ} 83^{\prime} \mathrm{N}$ latitude and $81^{\circ} 5^{\prime} \mathrm{E}$ longitude. It experiences hot humid summer and mild winter climate. Study included four levels of nitrogen (80, 120, 160 and $200 \mathrm{Kg}$ Nitrogen per hector) each replicated thrice in FRBD. The observations were recorded on various growth, yield and quality parameters.

The data obtained in respect to all the characters viz., plant height $(\mathrm{cm})$, plant spread $(\mathrm{cm})$, number of heading leaves per plant, number of loose leaves per plant, number of days to head initiation (days), number of days to head harvest (days), head circumference $(\mathrm{cm})$, head length $(\mathrm{cm})$, head volume $(\mathrm{cc})$, head compactness, head weight $(\mathrm{g})$, head yield per plot $(\mathrm{kg})$, estimated head yield per hectare (q), dry matter production (\%), anthocyanin content (mg $\left.100 \mathrm{~g}^{-1}\right)$, ascorbic acid(mg $\left.100 \mathrm{~g}^{-1}\right)$ and $\operatorname{TSS}\left({ }^{\circ}\right.$ Brix $)$ was subjected to the statistical analysis. The data were analyzed by the methods outlined by Panse and Sukhatme (1985) using the mean values of five random plants in each replication from all treatment to find out the significance of nitrogen levels.

\section{Results and Discussion}

\section{Growth parameters}

Plant height (cm), Plant spread (cm), number of heading and loose leaves per plant

It was observed that significantly highest plant height $(34.93 \mathrm{~cm})$, plant spread $(53.81 \mathrm{~cm})$, number of heading leaves per plant (23.18) and number of loose leaves per plant (13.87) was observed by $200 \mathrm{~kg}$ nitrogen per 
hector $\left(\mathrm{N}_{4}\right)$. However, the minimum plant height $(25.33 \mathrm{~cm})$, plant spread $(35.05 \mathrm{~cm})$, number of heading leaves per plant (15.93) and number of loose leaves per plant (9.63) was recorded with the $80 \mathrm{~kg}$ nitrogen per hector $\left(\mathrm{N}_{1}\right)$ (Table 1).

These above results are indicating the influence of nitrogen levels on all growth parameters. This might be due to better nutritional environment in the root zone for growth and development of plants and also nitrogen functions in plants by being part of chlorophyll which is responsible for photosynthesis, helps plants with rapid growth and improves the all growth parameters like plant height, plant spread, number of heading leaves per plant and number of loose leaves per plant. Similar results under different nitrogen levels were reported in cabbage (Mankar et al., 2015; Verma and Nawange, 2015)for plant height; With respect to plant spread $(\mathrm{cm})$, similar results were observed in cabbage (Verma and Nawange, 2015), broccoli (Singh et al., 2015), whereas the results were in line with findings in cabbage(Hossain et al., 2011), red cabbage (Manasa et al., 2017) and in broccoli (Singh et al., 2015)for number of heading leaves per plant and loose leaves per plant.

Number of days taken to head initiation and head harvest (days)

The minimum number of days taken to head initiation (46.77 days) and number of days taken to harvest (85.03 days) was recorded with $200 \mathrm{~kg}$ nitrogen per hector $\left(\mathrm{N}_{4}\right)$ which was significantly superior to with $160 \mathrm{~kg}$ nitrogen per hector $\left(\mathrm{N}_{3}\right)$ with 52.57and 87.14days to head initiation and harvest, respectively. Whereas the maximum number of days taken to head initiation (58.44 days) and number of days taken to head harvest (99.00 days) was recorded with $80 \mathrm{~kg}$ nitrogen per hector $\left(\mathrm{N}_{1}\right)$ (Table. 1).
Significantly minimum number of days to head initiation and harvest was might be due to favourable climatic conditions and sufficient quantity of fertilizers available during growth period which enhanced early head initiation and head harvest.

Successive increase in nitrogen levels decreased the number of days to head harvest and the increase in number of days to head initiation and head harvest might be due to the deficiency nitrogen prevailing during growth period which resulted in delayed head formation. These results are similarity in cabbage (Lavanya et al., 2014 and Naher et al., 2014), cauliflower (Mansoor et al., 2018) and broccolli (Dheerendra et al.,2012).

\section{Yield and yield attributing parameters}

\section{Head circumference $(\mathrm{cm})$ and Head length (cm)}

Significantly superior head circumference $(47.12 \mathrm{~cm})$ and head length $(16.77 \mathrm{~cm})$ was recorded with $200 \mathrm{~kg}$ nitrogen per hector $\left(\mathrm{N}_{4}\right)$, followed by $160 \mathrm{~kg}$ nitrogen per hector $\left(\mathrm{N}_{3}\right)$ with $(42.71 \mathrm{~cm})$ and head length $(14.96 \mathrm{~cm})$, whereas the minimum head circumference $(34.90 \mathrm{~cm})$ and head length $(11.65 \mathrm{~cm})$ was recorded with $80 \mathrm{~kg}$ nitrogen per hector $\left(\mathrm{N}_{1}\right)$ (Table. 2$)$.

These variations might be due to the increased supply of nitrogen might have accelerated synthesis of chlorophyll and amino acids and effective utilization of carbohydrates and their organic factors might have resulted in enlargement of head size viz head circumference and head length.

Similar findings have been reported in cabbage (Naher et al., 2014 and Hope et al., 2017) for head circumference. Whereas, in cabbage (Hossain et al., 2011) and broccoli (Singh et al., 2015) for head length. 


\section{Head volume (cc) and Head compactness}

It was observed that head volume and head compactness differed significantly with nitrogen levels in red cabbage. The highest head volume $(950.55 \mathrm{cc})$ and head compactness (0.51) was recorded with $200 \mathrm{~kg}$ nitrogen per hector $\left(\mathrm{N}_{4}\right)$, whereas the minimum head volume $(727.77 \mathrm{cc})$ and head compactness (0.77) was recorded with $80 \mathrm{~kg}$ nitrogen per hector $\left(\mathrm{N}_{1}\right)$ (Table. 2).

Head volume and head compactness exhibited a significant variation with nitrogen levels. Increased application of nitrogen significantly increased the growth parameters which might have synthesized more plant metabolites. Due to better availability of metabolites to plant, head volume and head compactness might have increased. Similar results have been reviled in cabbage (Lavanya et al., 2014; Verma and Nawange, 2015), cauliflower (Shree et al., 2014) for head volume, with respect to head compactness, similar findings have been reported in cabbage (Gamal et al., 2009)and cauliflower (Tekasangla et al., 2015).

Head weight (g), Head yield per plot $\left(\mathrm{kg} / \mathbf{1 2 . 8 7 \mathrm { m } ^ { 2 } )}\right.$

The data on head weight and head yield per plot revealed significant differences among different nitrogen levels. Significantly higher head weight $(616 \mathrm{~g})$ and head yield per plot $(49.26 \mathrm{~kg})$ was recorded with $200 \mathrm{~kg}$ nitrogen per hector $\left(\mathrm{N}_{4}\right)$, whereas the $80 \mathrm{~kg}$ nitrogen per hector $\left(\mathrm{N}_{1}\right)$ recorded lowest head weight $(358 \mathrm{~g})$ and head yield per plot $(28.63 \mathrm{~kg})$ (Table. 3). Results was clear that head weight and head yield per plot were significantly affected by nitrogen levels. Increased application of nitrogen significantly increases the growth parameters which might have synthesized more plant metabolites. Due to better availability of metabolites to plant, weight of head might have increased.

Results of head weight were in similar with findings in cabbage (Hossain et al., 2011 and Lavanya et al., 2014) and in cauliflower (Shree et al., 2014; Tekasangla et al., 2015). With respect to head yield per plot, Similar results findings with cabbage (Aquinas et al., 2005) and cauliflower (Mansoor et al., 2018).

\section{Estimated head yield per hectare (q) and Dry Matter Production (\%)}

Significantly higher estimated head yield per hectare $(382.15$ q) and dry matter production $(11.67 \%)$ was recorded with $200 \mathrm{~kg}$ nitrogen per hector $\left(\mathrm{N}_{4}\right)$, whereas the crop applied with on $80 \mathrm{~kg}$ nitrogen per hector $\left(\mathrm{N}_{1}\right)$ recorded the lowest estimated head yield per hectare (222.50 q) and dry matter production $(9.20 \%)$ (Table 3).

From the above results, it was clear that estimated head yield per hectare and dry matter production were significantly affected by nitrogen levels. As the nitrogen doses increases, the supply of nutrients and their utilization in plants also increases, which resulted in the more production of metabolites that enhances the production estimated head yield per hectare as well as dry matter production in red cabbage. Similar findings were reported in cabbage (Lavanya et al., 2014; Naher et al., 2014; Mankar et al., 2015), With regarding dry matter production, in cabbage (Akand et al., 2015). 
Table.1 Effect of nitrogen levels on growth parameters of red cabbage

\begin{tabular}{|c|c|c|c|c|c|c|}
\hline Treatment & $\begin{array}{c}\text { Plant } \\
\text { height }(\mathbf{c m}) \\
\text { at final } \\
\text { harvest }\end{array}$ & $\begin{array}{c}\text { Plant } \\
\text { spread }(\mathbf{c m}) \\
\text { at final } \\
\text { harvest }\end{array}$ & $\begin{array}{c}\text { No.of } \\
\text { heading } \\
\text { leaves } \\
\text { plant }^{-1}\end{array}$ & $\begin{array}{l}\text { No.of } \\
\text { loose } \\
\text { leaves } \\
\text { plant }^{-1}\end{array}$ & $\begin{array}{l}\text { No. of days } \\
\text { to head } \\
\text { initiation } \\
\text { (days) }\end{array}$ & $\begin{array}{c}\text { No. of days } \\
\text { to head } \\
\text { harvest } \\
\text { (days) }\end{array}$ \\
\hline N1: $80 \mathrm{~kg} \mathrm{~N} \mathrm{ha}^{-1}$ & 25.33 & 35.05 & 15.93 & 9.63 & 58.44 & 99.00 \\
\hline N2: $120 \mathrm{~kg} \mathrm{~N} \mathrm{ha}^{-1}$ & 28.58 & 41.39 & 17.73 & 10.74 & 55.49 & 93.47 \\
\hline N3: $160 \mathrm{~kg} \mathrm{~N}^{-1}$ & 31.75 & 47.59 & 20.29 & 12.20 & 52.57 & 87.14 \\
\hline N4: $200 \mathrm{~kg} \mathrm{~N} \mathrm{ha}^{-1}$ & 34.93 & 53.81 & 23.18 & 13.87 & 46.77 & 85.03 \\
\hline SEm \pm & 1.037 & 2.069 & 0.277 & 0.247 & 0.822 & 3.406 \\
\hline CD@ $9 \%$ & 3.062 & 6.107 & 0.817 & 0.729 & 2.427 & 10.055 \\
\hline
\end{tabular}

Table.2 Effect of nitrogen levels on yield attributing parameters of red cabbage

\begin{tabular}{|c|c|c|c|c|}
\hline Treatment & $\begin{array}{c}\text { Head } \\
\text { circumference } \\
(\mathbf{c m})\end{array}$ & $\begin{array}{c}\text { Head } \\
\text { length } \\
(\mathrm{cm})\end{array}$ & $\begin{array}{l}\text { Head } \\
\text { volume } \\
\text { (cc) }\end{array}$ & $\begin{array}{c}\text { Head } \\
\text { compactness }\end{array}$ \\
\hline N1: $80 \mathrm{~kg} \mathrm{~N}^{-1}$ & 34.90 & 11.65 & 727.77 & 0.77 \\
\hline N2: $120 \mathrm{~kg} \mathrm{~N} \mathrm{ha}^{-1}$ & 39.30 & 13.54 & 788.88 & 0.68 \\
\hline N3: $160 \mathrm{~kg} \mathrm{~N}^{-1}$ & 42.71 & 14.96 & 873.33 & 0.61 \\
\hline $\mathrm{N} 4: 200 \mathrm{~kg} \mathrm{~N}^{\mathrm{ha}}{ }^{-1}$ & 47.12 & 16.77 & 950.55 & 051 \\
\hline SEm \pm & 1.640 & 0.385 & 7.700 & 0.040 \\
\hline CD@ $@ 5 \%$ & 4.840 & 1.137 & 22.730 & 0.117 \\
\hline
\end{tabular}

Table.3 Effect of nitrogen levels on yield parameters of red cabbage

\begin{tabular}{|c|c|c|c|c|}
\hline Treatment & $\begin{array}{l}\text { Head } \\
\text { weight } \\
\text { (g) }\end{array}$ & $\begin{array}{c}\text { Head } \\
\text { yield plot } \\
\left(_{\left(\mathbf{k g} / 12.87 \mathbf{m}^{-1}\right)}\right.\end{array}$ & $\begin{array}{l}\text { Estimated } \\
\text { yield per } \\
\text { hectare }(q)\end{array}$ & $\begin{array}{c}\text { Dry matter } \\
\text { production } \\
(\%)\end{array}$ \\
\hline N1: $80 \mathrm{~kg} \mathrm{~N} \mathrm{ha}^{-1}$ & 358 & 28.63 & 222.50 & 9.20 \\
\hline $\mathrm{N} 2: 120 \mathrm{~kg} \mathrm{~N}^{-1}$ & 476 & 38.09 & 291.43 & 9.89 \\
\hline N3: $160 \mathrm{~kg} \mathrm{~N} \mathrm{ha}^{-1}$ & 541 & 43.30 & 336.41 & 10.76 \\
\hline N4: $200 \mathrm{~kg} \mathrm{~N} \mathrm{ha}^{-1}$ & 616 & 49.26 & 382.15 & 11.67 \\
\hline SEm \pm & 10.474 & 0.837 & 6.186 & 0.029 \\
\hline CD@ $9 \%$ & 30.720 & 2.471 & 18.261 & 0.085 \\
\hline
\end{tabular}

Table.4 Effect of nitrogen levels on quality parameters of red cabbage

\begin{tabular}{|c|c|c|c|}
\hline Treatment & $\begin{array}{c}\text { Anthocyanin content } \\
(\mathrm{mg} / \mathbf{1 0 0 g})\end{array}$ & $\begin{array}{c}\text { Ascorbic acid } \\
\text { content }(\mathrm{mg} / \mathbf{1 0 0 g})\end{array}$ & TSS $\left({ }^{0}\right.$ Brix $)$ \\
\hline N1: $80 \mathrm{~kg} \mathrm{~N} \mathrm{ha}^{-1}$ & 110.44 & 34.82 & 7.73 \\
\hline N2: $120 \mathrm{~kg} \mathrm{~N} \mathrm{ha}^{-1}$ & 112.22 & 35.91 & 7.90 \\
\hline N3: $160 \mathrm{~kg} \mathrm{~N} \mathrm{ha}^{-1}$ & 115.55 & 37.23 & 8.13 \\
\hline N4: $200 \mathrm{~kg} \mathrm{~N}^{-11}$ & 117.00 & 38.32 & 8.34 \\
\hline SEm \pm & 0.281 & 0.578 & 0.055 \\
\hline CD@ 5\% & 0.831 & 1.707 & 0.162 \\
\hline
\end{tabular}




\section{Quality parameters}

Anthocyanin content (mg/100g), Ascorbic acid content $(\mathrm{mg} / 100 \mathrm{~g})$ and TSS $\left({ }^{\circ} \mathrm{Brix}\right)$

With regarding quality parameters like anthocyanin content $(117 \mathrm{mg} / 100 \mathrm{~g})$, ascorbic acid content $(38.32 \mathrm{mg} / 100 \mathrm{~g})$ and TSS $\left(8.34^{\circ}\right.$ Brix) were recorded higher with $200 \mathrm{~kg}$ nitrogen per hector $\left(\mathrm{N}_{4}\right)$ compared to all other nitrogen levels. The lowest values for quality parameters like anthocyanin content (110.44 $\mathrm{mg} / 100 \mathrm{~g}$ ), ascorbic acid content (34.82 $\mathrm{mg} / 100 \mathrm{~g})$ and TSS $\left(7.73^{\circ} \mathrm{Brix}\right)$ were recorded with $80 \mathrm{~kg}$ nitrogen per hector $\left(\mathrm{N}_{1}\right)($ Table 4$)$.

The maximum anthocyanin content recorded with $200 \mathrm{~kg}$ nitrogen per hector $\left(\mathrm{N}_{4}\right)$ might be due to the sufficient level of nitrogen along with favourable climatic conditions prevailing during head formation stage. These results are in conformity with red cabbage (Manasa et al., 2017 and Patel et al., 2017) and broccoli (Vinod et al., 2017 and Vipul et al., 2017).

Based on the results obtained in the present investigation, it can be concluded that $200 \mathrm{~kg}$ nitrogen per hector $\left(\mathrm{N}_{4}\right)$ proved to be best for getting higher growth, yield, quality and economic returns in red cabbage for coastal Andhra Pradesh. Significantly higher values were recorded with vegetative parameters like plant height, plant spread and number of heading and loose leaves per plant leads to maximum photosynthetic activity and thereby facilitates better translocation of food material to economic parts. This might have resulted in obtaining higher values with yield parameters like volume of head, head circumference, head weight, head yield per plot, estimated head yield per hector and dry matter production with the above treatment $\left(\mathrm{N}_{4}\right)$ and the same was also maintained best quality with respect to anthocyanin content, ascorbic acid content and TSS.Red cabbage applied with $80 \mathrm{~kg}$ nitrogen per hector $\left(\mathrm{N}_{1}\right)$ recorded the lowest values for vegetative and yield parameters. The crop applied with lower dose of nitrogen received very less quantity of nitrogen level which is not conducive for red cabbage. The deficiency of nitrogen content during the crop growth period restricted the photosynthetic activity and translocation of food materials that might have resulted in poor vegetative growth leading to lesser yields and quality with the above treatment $\left(\mathrm{N}_{1}\right)$.

\section{References}

Akand, M. H., Khairulmazed, H. E. M. and Ashraful, M. 2015. Influence of different dose of nitrogen on the growth and yield of cabbage (Brassica oleracea var. capitata L.). International Journal on Multidisciplinary Research and Development, 2(2): 11-14.

Aquinas, A. L., Puiatii, M. and Pereira, F. P. 2005. Effect of spacing and nitrogen on the qualitative characteristics of production of cabbage. Horticulture Brazil. Brasilia, 23(1): 100-04.

Arakari, H. R., Chalam, L. V., Satyanarayana, P. and Donathus, K.L. 1956. Soil Management in India. Asia Publication House, Mumbai.

Dheerendra, K., Tripathi, S.M., Dwivedi, A.K. and Vivek, P. 2012. Effect of N and P on crop growth, head yield and quality of broccoli. Horti flora Research Spectrum. 1(2): 172-74.

Gamal, R., Abdalla, G., Ahmad, A., Mahmoud, A. E. and Amira, H. 2009.Cabbage nutritional quality as influenced by planting density and nitrogen fertilization. Fruit, Vegetable and Cereal Science and Biotechnology, 3 (1), 68-74.

Hossain, D., Haque, A. M., Abuyusuf, M., Riad, M. M., Hussain.andIqbal, A.S. M. 2011. Response of cabbage to different levels of fertilizer application 
in salna silty clay loam soil. Bangladesh Research Publication Journal, 6(2): 155-66.

Hope, K. N., Dawuda, M. M. and Otabil, A. 2017. Variety and NPK rate effect on growth and yield of cabbage (Brassica oleracea $\mathrm{L}$.) in the bediese soil series at asantemampong in Ghana. Advances Research, 8(3): 1-6.

Lavanya, P., Umajyothi, K., Ushakumari, K., and Sasikala, K. 2015. Effect of dates of planting and nitrogen on growth and yield of cabbage (Brassica oleracea var. capitata. L) cvRadha. M.Sc (Hort) Thesis, Dr.Y.S. R. Horticulture University, Andhra Pradesh.

Mankar, A., Kumari, C. and Karuna, K. 2015. Effect of nitrogen levels and microbial inoculants on growth, yield and quality of cabbage.Progressive Horticulture, 47(2): 296-99.

Manasa, S.Mukunda Lakshmi, L. Syed Sadarunnisaand Rajasekharam, T. 2017. Effect of plant densities and nitrogen levels on growth and yield of red cabbage (Brassica oleracea var. capitata f. rubra) M.Sc (Hort) Thesis, Dr.Y.S.R. Horticulture University, AndhraPradesh.

Mansoor, A. S., Mujahid, H. L., Altaf, H. A., Asif, A. H., Aftab, A. K., Waqar. A. K., Fahad, R. L., Abdul, Q. G. and Niaz, A. W. 2018. Effect of various levels of nitrogen and phosphorus on plant growth and curd yield of cauliflower (Brassica oleracea L.).International Journal of Development Research, 8(3):19184188.

More, K. 2006. Response of cabbage (Brassica oleraceavarcapitata) transplants to nitrogen, phosphorus and potassium nutrition. Desertification submitted for the Master of Science. Department of Plant Production and Soil Science in the faculty of Natural and Agricultural Sciences, University of Pretoria, Pretoria.

Naher, M. N. A., Alam, M. N. and Jahan, N. 2014.Effect of nutrient management on the growth and yield of Cabbage (Brassica oleracea var. capitata L.) in calcareous soils of Bangladesh.The Agriculturists, 12(2): 24-33.

National Hotriculture Board.2018-2019. Indian Journal of Agriculture Data Base.1-3p. www.nhb.com.

Panse, V. G. and Sukhatme P. V. 1985.Statistical methods for agricultural workers.Indian Council of Agricultural Research.New Delhi.1-20.

Patel, H. R and Tripathi, S. 2017. Response of Red Cabbage (Brassica oleraceavar. capitata f. rubra) to $\mathrm{N}$ and $\mathrm{P}$ levels under South Gujarat condition. M.Sc (Hort) Thesis, Navsari Agricultural University, Gujarat.

Singh, K. M., Chand, T., Kumar, M., Singh, K. V., Lodhi, S. K., Singh, V. P and Sirohi, S. V. 2015. Response of different doses of NPK and boron on growth and yield of broccoli (Brassica oleracea L. var. italica).International Journal Biological Science and Management, 6(1): 108-12.

Shree, S., Singh, V. K. and Kumar R. 2014.Effect of integrated nutrient management on yield and quality of cauliflower (Brassica oleracea var. botrytis L.).The Bioscan, 9(3): 105358.

Tekasangla, S. P., Kanaujla and Singh, P. K. 2015.Integrated nutrient management for quality production of cauliflower in acid alfisol of Nagaland.Karnataka Journal of Agriculture Science, 28(2): 244-47.

Verma, H. and Nawange, D. D. 2015.Effect of different levels of nitrogen and sulphur on the growth, yield and quality of cabbage (Brassica oleraceaL. var. capitata).Agriculture Science Digest, 
35(2): 152-54.

Vinod, S., Aravindakshan, K.and Bola, P. K. 2017. Effect of sowing date and spacing on growth, yield and quality of Broccoli (Brassica oleracea var. italica) var. Green Head.Chemistry Science Review Letter, 6(21), 209-12.

Vipul, P. S., Prasad, V. M. and Deepanshu. 2017. Effect of sowing date on growth and yield of broccoli (Brassica oleracea var. italica). Plant Archives, 17(2):1063-70.

Wojciechowska, R. S. and Kołton, A. 2007. The content of some nutrients in red cabbage yield depending on the form of nitrogen fertilizer. 41: 667-71.

Yuan, Y., Chiu, L. and Li, L. 2009. Transcriptional regulation of anthocyanin biosynthesis in red cabbage.Planta, 230: 1141-53.

\section{How to cite this article:}

Abhilash Kavalgi, R. Rajyalakshmi, K. Uma Jyothi and Uma Krishna, K. 2020. Studies on the Effect of Nitrogen Levels on Growth, Yield Components and Quality of Red Cabbage (Brassica oleracea var. capitata f. rubra). Int.J.Curr.Microbiol.App.Sci. 9(01): 367-374.

doi: https://doi.org/10.20546/ijcmas.2020.901.041 